International Journal of Educational Methodology
Volume 4, Issue 3, 109- 124.
ISSN: $2469-9632$
http://www.ijem.com/

\title{
Why Does The Use of Social Network Site (SNS) Make Happy? : A Qualitative Analysis
}

\author{
Ugur Dogan * \\ Humeyra Uysal \\ Sabri Sidekli \\ Mugla Sitki Kocman University, TURKEY Mugla Sitki Kocman University, TURKEY Mugla Sitki Kocman University, TURKEY
}

Received: March 4, 2018 - Revised: March 26, 2018 - Accepted: June 16, 2018

\begin{abstract}
The aim of this study investigate to the reasons why the usage of Social Network Sites (SNS) makes users happy. To this end, the study was conducted with as a qualitative research method. The phenomenological design, which is a qualitative research method, was utilized for determining why SNS usage cause happiness and having a better to understand of how SNS users describ e SNSs and what they feel about it. The study group was composed of 137 university students (60 males and 77 females) attending the Faculty of Education, Faculty of Science, Faculty of Literature, and Faculty of Economics and Administrative Sciences at a un iversity in the southwestern of Turkey. A structured, open-ended interview was used as the data collection instrument. The contributors were asked the question "Why does SNS usage cause happiness?" and their answers were retrieved. The answers were encoded and entered to the NVivo software to conduct analyses. Based on the most frequent answers of the participan ts, three different experts were consulted and seven themes were created accordingly. These seven themes include Need for Stroke, Self -Concealment, Ease of Interaction, Ease of Accessing and Disseminating Information, Ease of Shopping, Leisure Activity, and Fear of Missing Out. Subcategories were also created for these seven themes. It was concluded that the theme of FoMO is nourished by all other the mes.
\end{abstract}

Keywords: University student, social network cites usage, happiness, qualitative analysis, fear of missing out.

To cite this article: Dogan, U., Uysal H., \& Sidekli, S. (2018). Why does the use of social network site (sns) make happy?: A qualitative analysis. International Journal of Educational Methodology, 4(3), 109-124.doi: 10.12973/ijem.4.3.109

\section{Introduction}

According to the report published by Kemp (2017), there are 3.77 billion internet users globally and 2.80 billion of them have social media accounts. Furthermore, an increase of $30 \%$ in mobile phone usage has occurred while there has been a decrease in computer usage. 2016 saw an increase of $10 \%$ in internet usage compared to 2015 and, number of social network site (SNS) users increased at 21\%. Almost half a billion (482 million) new users opened SNS accounts. Especially in Facebook, which is one of the most popular SNSs, an annual increase of 24\% was seen in 2016 with 363 million active users monthly. Other most popular applications following Facebook include FB Messenger, WhatsApp and YouTube.

Kemp's (2017) report states that there are 48 million active internet us ers in Turkey. Based on the data of "Address Based Population Registration System" results by TUIK (2016), Turkey's population has been 79,814,871 as of December 2016. It can be concluded between Kemp's (2017) report and TUIK (2016) data that more than half of Turkey's population is an internet us er. TUIK (2016) also stated in the report of "Research on Household Usage of Information Technologies" that eight out of every ten households have access to internet and 55.9\% of the population use internet. The internet us er rate among 16-to-24-year-old youngsters is 50.5\% (Buckle, 2017; Young, 2016). Furthermore, the num ber of regular internet us ers and the number of thos e who use internet every day or at least once a week have also increased. As for the purposes of internet users in Turkey, creating a profile on SNSs takes the first place with $82.4 \%$ and the number of active SNS us ers inc reased at 14\% (Kemp, 2017; TUIK, 2016). Creating profiles on SNSs is followed by sending messages, sharing photos, watching videos, reading news, info search about heal th, info about goods and services, and listening to music (TUIK, 2016; Sidekli, 2013a; Sidekli, 2013b). Unlike the world, the mostly used SNS in Turkey is not Facebook but YouTube at 57\%. YouTube is the most popular social network in Turkey. The second most popular SNS is Facebook at 54\% which is followed by Instagram (45\%), Twitter (44\%), and WhatsApp (40\%).

The media in which internet users define themselves, interact with internet users from diverse cultures and countries and communicate with each other with symbols that imitate gestures and mimics they use in real life are called "social

\footnotetext{
* Corresponding Author:

Ugur Dogan, Mugla Sitki Kocman University, Faculty of Education, Department of Educational Science, Turkey.

E-mail: ugurdogn@gmail.com
} 
network" (Koc \& Karabatak, 2012). SNS is a cyber environment which allows individuals to create profiles, share texts, pictures and photos and connect with other individuals who are the members of social networks via internet applications and groups (Boyd \& Ellison, 2008; Pfeil, Arjan \& Zaphiris, 2009; Powell, 2009; Tapscott, 2008). An SNS is composed of online or offline communities based on membership (Pempek, Yermolayeva \& Calvert, 2009). By definition, SNSs offer members a new metho d and environment of communication and individuals who are members of social networks use computers as shared instruments for facilitating the group creation process and expanding the group scope and influence (Kane, Fichman, Gallaugher \& Glaser, 2009; Pfeil, Arjan \& Zaphiris, 2009; Ross et al., 2009). SNSs also enable individuals to elude their real personalities and have a new identity thanks to new profiles they created (Acir, 2008). Furthermore, the purposes of using social media use may include maintain a connection with friends, learning about news and current events, while away, the us age on account of friends' us age, commu nicating with o thers, using it for fun, sharing photos and videos, expressing opinions, coming together new people, and look for and buy things (McGrath, 2017).

It is observed in the literature that there are increased number of studies on SNS usage and how it affects human psychology, for what purposes SN Ss are used and what impacts they have on individuals (Boyd \& Ellison, 2008; Do gan, 2016; Ellison, Steinfeld \& Lampe, 2007; Kwon \& Wen, 2010; McAndrew \& Jeong, 2012; Murray, 2008; Muscanell \& Guadagno, 2012; Pfeil, Arjan \& Zaphiris, 2009; Powell, 2009; Tapscott, 2008; Tifferet \& Vilnai-Yavetz, 2014). SN Ss offer individuals opportunities such as expressing oneself, creating communities; cooperation; sharing, convenience of information sharing, establishing and maintaining new relationships (Kwon \& Wen, 2010; Murray, 2008). In general, individuals become members of SNSs for establishing and maintaining social connections, creating social and vocational networks, receiving and sharing ideas and opinions, and fi nding out new information (Ellison, Steinfeld \& Lampe, 2007). Yet, wom en and men have different purposes when becoming a member of SNS. Women mainly focus on establishing relationships and family activities when they sign up on SNSs whereas men try to show themselves up (McAndrew \& Jeong, 2012; Muscanell \& Guadagno, 2012; Tifferet \& Vilnai-Yavetz, 2014).

SNS users have 2.82 active accounts on av erage (Mander, 2015). One of the reasons why individuals use SNSs on such a scale is that communication via SNS is very easy and affordable (Valkenburg, Peter \& Schouten, 2006). The report by McGrath (2017) lists the causes of using social media. 40\% of the individuals in the study explained that they us e it for communicating, making use of their free time, being informed of current events, and sharing their daily lives on internet. It is stated that 16-to-24-year-old youngsters use SNSs rather for keeping themselves busy (Mander, 2015; McGrath, 2017). It has been observed that Facebook us ers share photos for purposes such as love, need for attention, explanation, habit, inform ation sharing and satisfaction of social impact requirements, that photos and images play a key role in satisfying the needs for social, affection and love and meeting such needs may ease loneli ness (Malik, Dhir \& Nieminen, 2015). Pittm an (2015) concluded that Instagram users ease their feelings of loneliness as they use this SNS. It was also stated in the study that SNS overcome loneliness, users become happy when using thes e netwo rks and think that they bring closeness and intimacy to them (Pittman \& Reich, 2016).

Happiness is defined as pleasure found as a result of achieving all longings completely and constantly (Turkish Language Association, 2011) or the feeling or showing pleasure or contentment (Oxford, 2017). According to Layard (2005), happiness is the pleasure of individuals with their own lives and how they feel perfect. Happiness is also handled as a concept measured with brain waves. (Kahneman, Diener \& Schwarz, 1999). B ulbul and Giray (2011) explained level of happiness along with happiness its elf as follows: it is how positive an individual assesses the total quality of his/her life in general. Eryilmaz (2011) argues that the less negative emotions the more positive motions an individual has in his/her life, the higher level of happiness they get. In recent years, studies have found that SNSs are effective in increased level of happiness and concluded that individuals use SNSs bec ause they are happy and perform activities they enjoy (Dogan, 2016; Eren, Celik \& Akturk, 2014; Sener, 2009).

\section{Methodology}

\section{Research Goal}

This study aims to understand why SNS usage makes youngs ters happy in accordance with university student opinions and experiences. The study will help the evolution of appropriate policy for studies on problematic internet usage, internet addiction, and technology addiction. To this end, the answer to the following question was sought for:

\section{Why does the use of SNS make happy?}

\section{Research Design}

The qualitative research method was used for find out the reasons why SNS usage makes the participants in the study group happy in this study. Qualitative research is defined as the research in which qualitative data collection methods such as observation, interview, and document analysis are used and a qualitative process is followed for putting forth perceptions and events in a realistic and holistic manner in their natural environments. In other words, qualitative research features investigating the social phenomena in their associated environments with an approach based on theo rization (Yildirim \& Simsek, 2013). The phenomenological design, which is a qualitative research method, was used 
in the research. The phenomenological design is about how individuals see thems elves and the world around them. It generally tri es to explain implicit and unnoticed meanings of their real-life experiences (Robson, 2015: 186). It also focuses on how person understand, define a given phenomenon, what they sense about it, how they judge, recall and make sense of it and what they tell others about it (Patton, 2014).

\section{Study Group}

In phenomenological research, participants are chosen among individuals who have experiences associated with the subject of research and can express or reflect these experiences properly (Yildirim \& Simsek, 2015). The criterion sampling method was used when choosing the participants of the research. In criterion sampling, the researcher uses his/her own judgment about whom to participate in the research and include those who are the most suitable for the research in the sample. The individuals who possess the attributes identified by the res earch on average are included in the sample (Balci, 2015). The criteria used in the selection of participants in the research were that having a smartphone and an internet package, having at least one SNS account or using SNS applications actively. Accordingly, an interview was performed with the students in the Faculty of Education, Faculty of Science, Faculty of Literature and Faculty of Economics and Administrative Sciences at a university in the southwestern Turkey. The participants were informed on aim of interview, and it was declared that interviews would be performed and they were to be recorded with a voice recorder during the research process. The all participations were volunteer. Demographics of the participants who participated in the study are shown in Table 1.

Table 1. Demographics of the study group

\begin{tabular}{|c|c|c|c|c|c|c|c|}
\hline Variable & & $\mathrm{N}$ & $\%$ & Variable & & $\mathrm{N}$ & $\%$ \\
\hline \multirow{2}{*}{ Gender } & Male & 60 & 44 & \multirow{4}{*}{ Faculty } & Education & 31 & 23 \\
\hline & Female & 77 & 56 & & Science & 28 & 20 \\
\hline \multirow{7}{*}{ Age } & 17 & 1 & 1 & & Literature & 33 & 24 \\
\hline & 18 & 14 & 10 & & Economics & 45 & 33 \\
\hline & 19 & 10 & 7 & \multirow{5}{*}{$\begin{array}{l}\text { Number of SNS } \\
\text { account }\end{array}$} & 1 & 15 & 11 \\
\hline & 20 & 36 & 26 & & 2 & 22 & 16 \\
\hline & 21 & 33 & 24 & & 3 & 63 & 46 \\
\hline & 22 & 27 & 20 & & 4 & 24 & 18 \\
\hline & $23+$ & 16 & 12 & & $5+$ & 9 & 7 \\
\hline \multirow{6}{*}{$\begin{array}{l}\text { Average SNS } \\
\text { hours (Daily) }\end{array}$} & 1 & 10 & 7 & \multirow{6}{*}{$\begin{array}{l}\text { Average number of } \\
\text { SNS friends }\end{array}$} & $0-50$ & 1 & 1 \\
\hline & 2 & 12 & 9 & & $51-100$ & 6 & 4 \\
\hline & 3 & 20 & 15 & & $101-150$ & 16 & 12 \\
\hline & 4 & 44 & 32 & & $151-200$ & 28 & 20 \\
\hline & 5 & 36 & 26 & & $201-250$ & 37 & 27 \\
\hline & 6 & 15 & 11 & & $250+$ & 50 & 36 \\
\hline
\end{tabular}

\section{Data Collection Instruments}

As primary data collection instrument in phenomenological research is interviews (Yildirim \& Simsek, 2015), the data were collected in interviews, too, in this research. If a flexible, comfortable and empathic environment can be provided for participants in interviews, they will express the experiences and emotions which they are not even aware of (Yildirim \& Simsek, 2015: 81).

A structured interview form was utilized in interviews. The interview form comprises of an open -ended item: Why does the use of SNS make happy? No additional item was asked depending on the answers given by the students. The interview data were obtained in the in terviews with 137 students who were attending the Faculty of Education, Facul ty of Science, Faculty of Literature and Faculty of Economics and Administrative Sciences at a university in the southwestern Turkey in the spring term of 2016-2017 academic year. Six interviews a day were performed by the researchers in seven days. The first researcher conducted 42, the second researcher conducted 39 and the third researcher conducted 36 interviews. The interviews were taped with a voice recorder, and a voice record of 118 minutes was achieved within the scope of the research with the shortest interview being 45 seconds. The voice records were decoded into the computer environment word by word and a document of 29 pages in total was obtained. The texts were presented to the interviewee students in hard copies, they were allowed to make changes on the texts, and the texts were finalized upon the approval of the teachers.

\section{Analyzing of Data}

The data obtained in the research were analyzed with the content analysis technique. Content analysis is defined as a systematical, repeatable technique in which some of the words in a text are summarized in smaller content categories with coding based on certain rules. It aims to identify given concepts or subjects in texts (Buy ukozturk, Kilic Cakmak, Akgun, Karadeniz \& Demirel, 2014). NVivo 11, which is a computer bas ed qualitative data analysis software, was used in the data analysis of researh. The induction way was used throughout the content analysis. The responses given by 
the participants to the research question were examined word by word and sentence by sentence to create codes through in-vivo encoding feature in NVivo. While the coding process, the words used by the participants when stating their opinions were used and the codes were created through direct citations. The nam es of them es to include similar codes were defined by the researchers and the in-vivo codes were gathered in shared categories and categories were gathered in appropriate themes. In the assumption process, categories were achieved through in -vivo codes, subthemes through categories, and main theme through subthemes where necessary.

The encoding and thematization process was carry outed by the three researchers separately in the data analysis. Encoding by different researchers increases the reliability of the research. Karasar (1982) mentions about the agreement between independent observers. Agreement between independent observers argues that the closer data outcomes obtained by independent observers are, the more reliable the study is. Special techniques of analysis of variance are utilized in the calculation of agreement between independent observers (Buyukozturk, Kilic Cakmak, Akgun, Karadeniz \& Demirel, 2014). Also for achieving the validity and reliability of the outcomes in the study, the research process was explained particularly and the data were presented with overall and direct citation as much as possible (Yildirim \& Simsek, 2015).

Themes defined during the analysis and relationships among them were illustrated with Dia software. Shared opinions and individual opinions were bringing in these figures. Therefore, the themes could be based on a single participants' opinion as well as group opinions. The themes were correlated and examined in a holistic way to get explanatory outcomes in the data analysis, and the data were understandably defined in an effort. Furthermore, some of the in -vivo codes were encoded in multiple categories and themes as they can define multiple categories. Likewise, some of the themes were encoded in multiple main themes or themes in consideration that they represent multiple main themes.

\section{Findings}

\section{Why does the use of SNS make happy?}

Themes composed of university students' opinions on Why does the use of SNS make happy are presented in Figure 1. We can see the themes as a whole include self-concealment, ease of accessing and disseminating information, ease of interaction, leisure activity, ease of shopping, keeping record of history, fear of missing out, achieving the idealized selfeasier, and need for appreciation in the figure.

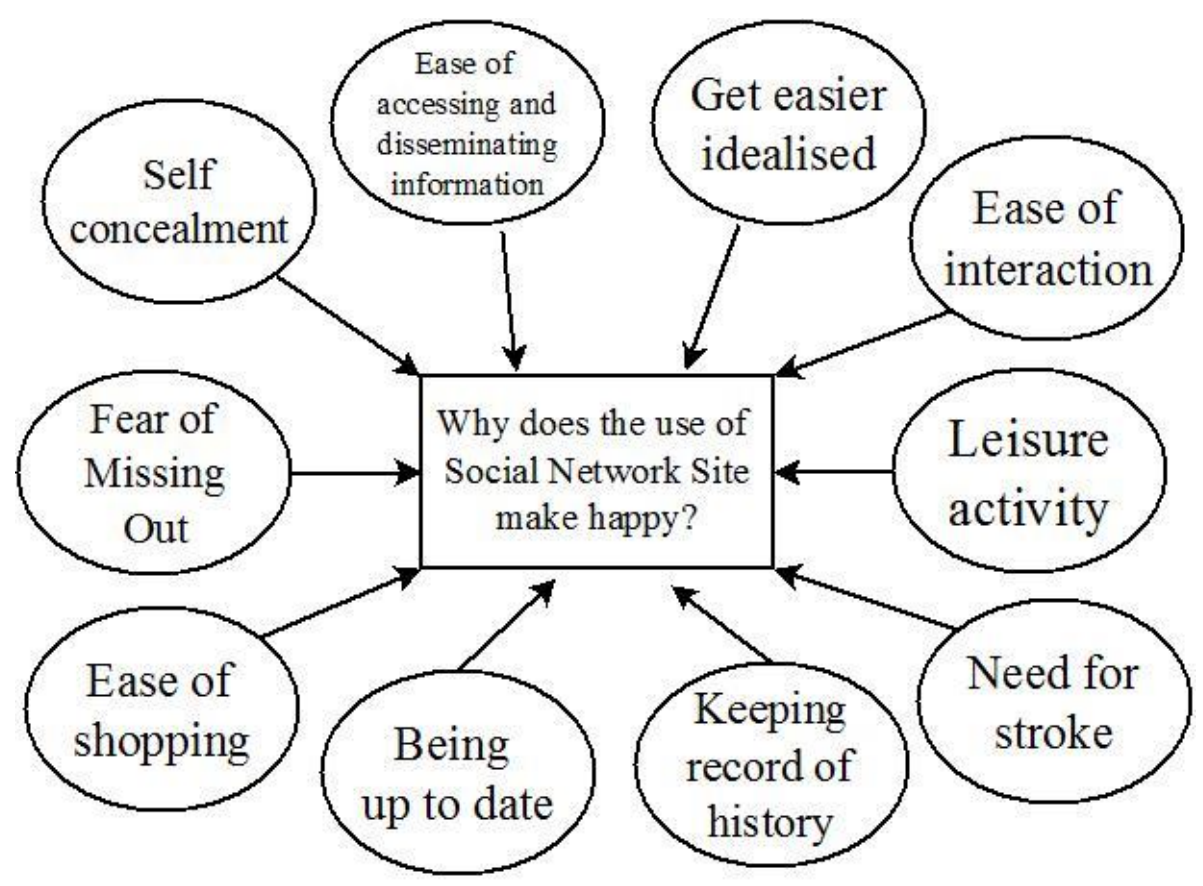

Figure 1. Why does the use of SNS make happy - holistic overview

While the theme of keeping record of history $(\mathrm{f}=8)$ has no $\mathrm{c}$ ategories, all other them es have their categories. As seen in the following student speech for the theme of keeping record of history: "I tweet about the things and funny jokes that come to my mind and eternalize them right away", "I post something I do or don't like during the day in the social media in written", "It's like 'I'm here doing this, I like this post, I'm visiting som e plac e'", "I add value and meaning to the places I go and see and say 'I'm here now"' and "You can inform everyone about what's new with you and it becomes permanent." 


\section{Need for appreciation/ Popularity, appreciation and approval}

One of the themes associated with Why does the use of SNS make happy is "Need for appreciation/Popularity, appreciation and approval" given in Figure 2. The categories that constituted this theme include "Satisfying the desire of appreciation", "Desire of popularity”, "I can say; I'm not alone”, "I'm here and I exist, too", "Making me feel valuable”, "Feeling cared about", and "It provides self-confidence."

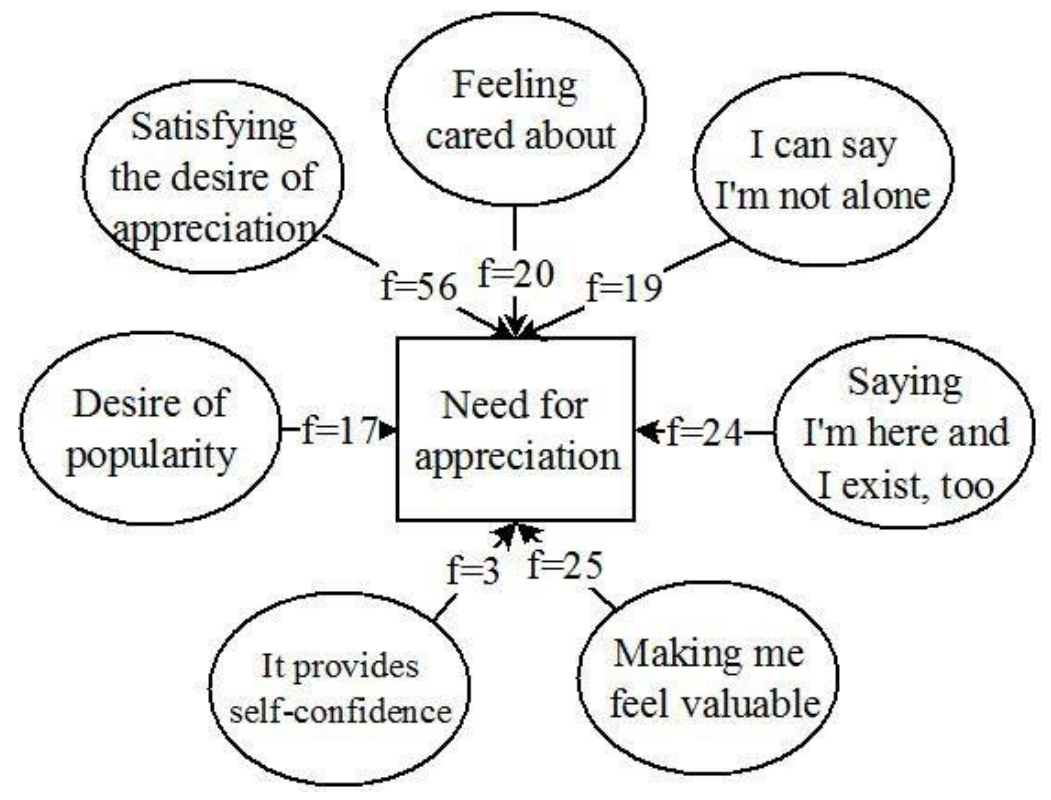

Figure 2. Why does the use of SNS make happy - Need for appreciation.

We can see that the category with the highest frequency in the theme of need for appreciation is "Satisfying the desire of popularity" $(\mathrm{f}=56)$. As an example, Student 18 provided the statement "Being appreciated by people makes you happy even though it is symbolic and not expressed" for this category. In another category, "Making me feel valuable" $(\mathrm{f}=25)$, Student 109 said "Likes and positive comments under the photos make you feel valuable." For another category of this them e which is "I'm here and I exist, too" ( $\mathrm{f}=24)$, Student 69' statement "It's like 'I'm here doing this, I like this post, I'm visiting some place"' can be pres ented as an example. In another category, "Feeling cared about" (f=20), one of the students provided the statement "If nobody pays attention to you, you log into a social network and can leave the impression of someone who is extrem ely active and popular." Another category of this theme which is "I can say I'm not alone" ( $\mathrm{f}=19$ ) can be exemplified with Student 130's statement "Being liked on Twitter shows me that I'm not the only one who comes up with that thought, that is, I'm not alone." The category "Desire of popularity" (f=17) can be exemplified with the statement "It increases popularity and they feel renown and appreciated persons and become happy." The final category of the Need for appreciation/Popularity, appreciation and approval theme is "It provides self-confidence" $(\mathrm{f}=3)$. We can see the statements "It increases self-confidence in relationships with opposite sex", "Feedbacks from others increase people's self-confidence", and "Liked videos, words, or photos give self-confidence."

\section{Self-Concealment}

Another theme associated with why does the use of SNS make happy is "Self-concealment" given in Figure 3. The subthemes of self-concealment are "Stalking", "Area where one feels safe and expresses ideas freely", and "achieving the idealized self easier". 


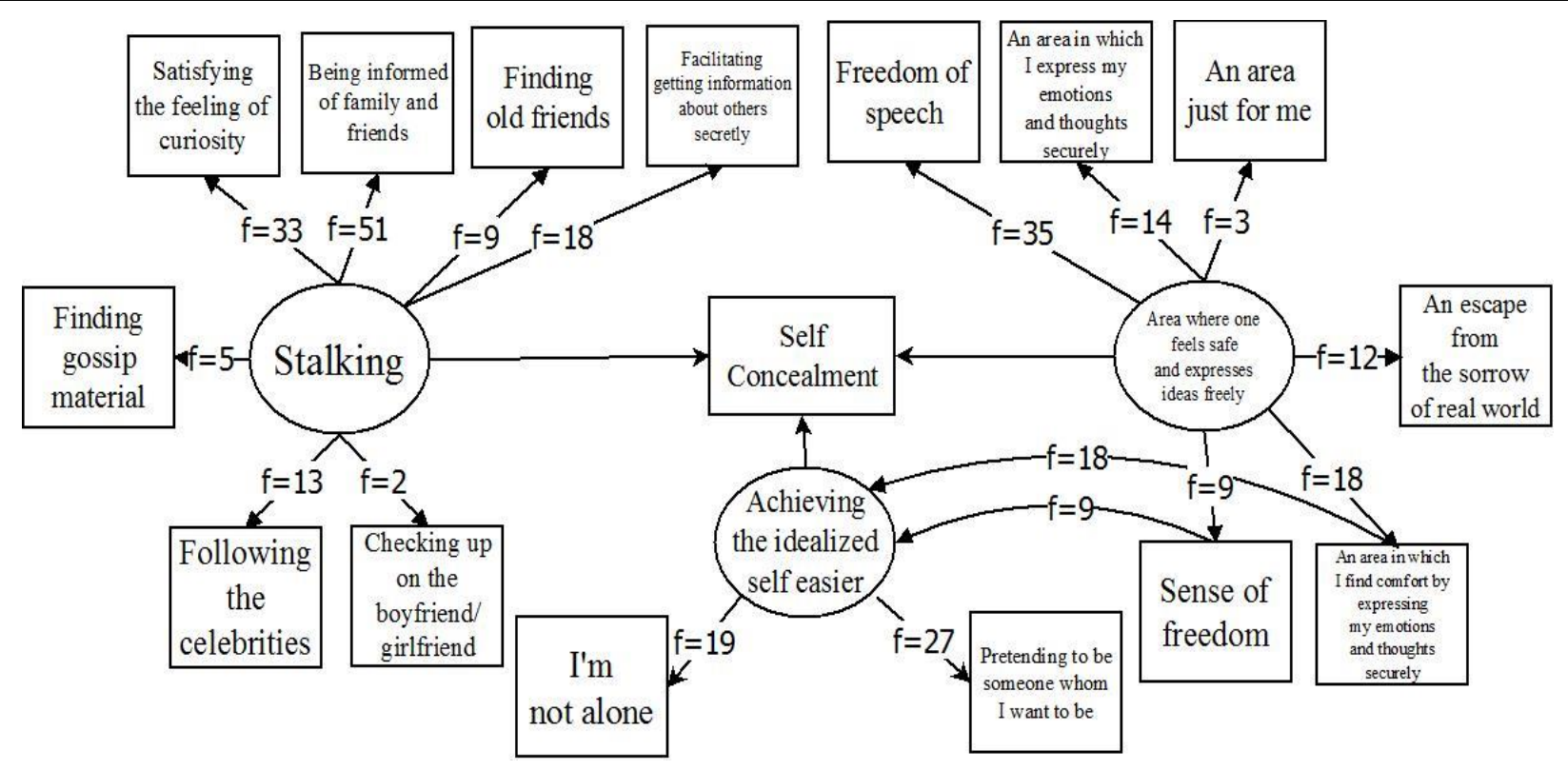

Figure 3. Why does the use of SNS make happy - Self-concealment

The first subtheme to be addressed under the self-concealment theme is "Stalking" (Being inform ed of family and friends, Satisfying the feeling of curiosity, Facilitating getting information about others secretly, Following the celebrities, Finding old friends, Finding gossip material, and Checking up on the boyfriend/girlfriend). It was found that the category with the highest frequency in the Stalking subtheme was "Being informed of family and friends" ( $\mathrm{f}=51$ ). This category can be exem plified with Student 32's statement "Bec ause I look at my friends and relatives and it makes me happy to know what they do, where they are in life, in what provinces they live and in what effort they go into." This category is followed by "Satisfying the feeling of curiosity" ( $\mathrm{f}=33$ ) which can be exemplified with Student 45 's statement "I satisfy my curiosity by following their posts when I want to know what they are up to." The next category was found to be "Facilitating getting information about others secretly" ( $\mathrm{f}=18)$. This category can be exemplified with Student 114's statement "I can somehow find people on social networks and become more or less informed of their lives and they don't know about this." Another category in the Stalking subtheme is "Following the celebrities" ( $\mathrm{f}=13$ ). which can be exemplified with Student 85's statement "I look at celebrities' posts on Twitter and find interesting information about their lifestyles." The next category was found to be "Finding old friends" ( $\mathrm{f}=9$ ). Student 25's statement "I become happy when I find a friend of mine whom I haven't seen since primary school and we exchan ge messages on Fac ebook" can be presented an example for this category. Another category in the Stalking subtheme is "Finding gossip material" $(\mathrm{f}=5)$. This category can be exemplified with Student 11's statement "You find gossip material easily and without much effort." The final category in the Stalking subtheme is "Checking up on the boyfriend/girlfriend" ( $f=2$ ) which can be exemplified with Student 14's statement "I can easily understand whether my boyfriend/girlfriend even do anything secretly."

The second subtheme of Self-concealment is "Area where one feels safe and expresses ideas freely" (Freedom of speech, An area in which I find comfort by expressing my emotions and thoughts securely, An area in which I express my emotions and thoughts securely, An escape from the sorrow of real world, sense of freedom, sense of freedom and an area just for me). It was seen that the category with the highest frequency in this subtheme was "Freedom of speech" $(\mathrm{f}=35)$. This category can be exemplified with Student 60's statement "I'm happy because I can share my thoughts freely." The next category of the "Area where one feels safe and expresses ideas freely" subtheme is "An area in which I find comfort by expressing my emotions and thoughts securely" ( $\mathrm{f}=18$ ) which can be exemplified by Student 6's statement "As we can express what we feel and think freely and more comfortably on social networks, these m edia can make us happy." Another category of the "Area where one feels safe and expresses ideas freely" subtheme is "An area in which I express my emotions and thoughts securely" ( $\mathrm{f}=14$ ) which can be exemplified with Student 95's statement "We can reflect our emotions more comfortably, therefore we can feel more secure there." "An escape from the sorrow of real world" ( $\mathrm{f}=12$ ) which is another category of this subtheme can be exemplified with Student 47's statement "As long as you don't enjoy existing in the real life, you start using social networks even more." Another category of the "Area where one feels safe and expresses ideas freely" subtheme is "Sense of freedom" (f=9) which can be exemplified with Student 37's s tudent "It is pleasant to express myself comfortably." The final category of the "Area where one feels safe and expresses ideas freely" subtheme is "An area just for me" ( $\mathrm{f}=3$ ). This category can be exemplified with Student 104 's statement "I have a place that belongs to me, that is, just for me."

The third and last subtheme of Self-conc ealm ent is "Achieving the idealized self easier" (I'm not alone, Pretending to be someone whom I want to be, Sense of freedom, An area in which I find comfort by expressing my emotions and thoughts securely). The category with the highest frequency in the subtheme of "Achieving the idealized self easier" is 
"Pretending to be someone whom I want to be" ( $\mathrm{f}=27$ ). This category can be exemplified with Student 73's statement "I'm happy because I can share my thoughts freely." "I'm not alone" ( $f=19)$ which is another category of this subtheme can be exemplified with Student 65's statement "I find comfort on the computer by thinking that there are people like me." The next category of the "Achieving the idealized self easier" is "An area in which I find comfort by expressing my emotions and thoughts securely" ( $\mathrm{f}=18)$ which can be exemplified with Student 9's statem ent "People who are shier about making friends, socializing and sharing their thoughts can act more comfortably and express themselves better on social networks." The final category of this subtheme is "Sense of freedom" ( $\mathrm{f}=9$ ) and this category can be exemplified with Student 9's statement "I act more comfortably in virtual environment compared to social environment."

As seen in Figure 3, two categories (sense of freedom and an area in which I find comfort by expressing my emotions and thoughts securely) were observed both in the "Achieving the idealized self easier" and "Area where one feels safe and expresses ideas freely" subthemes.

\section{Ease of Interaction}

Another theme associated with why does the use of SNS make happy is "Ease of Interaction" given in Figure 4. We can observe the following categories in the Ease of Interaction theme: "Sharing fine moments", "Opportunity to get socialized", "Ease of making friends", "Affordable and easy communication", "Exchange of ideas", "Opportunity to reach more people", "Finding old fri ends", "Interacting with others", "Ease of communication with opposite sex", and "Finding partners".

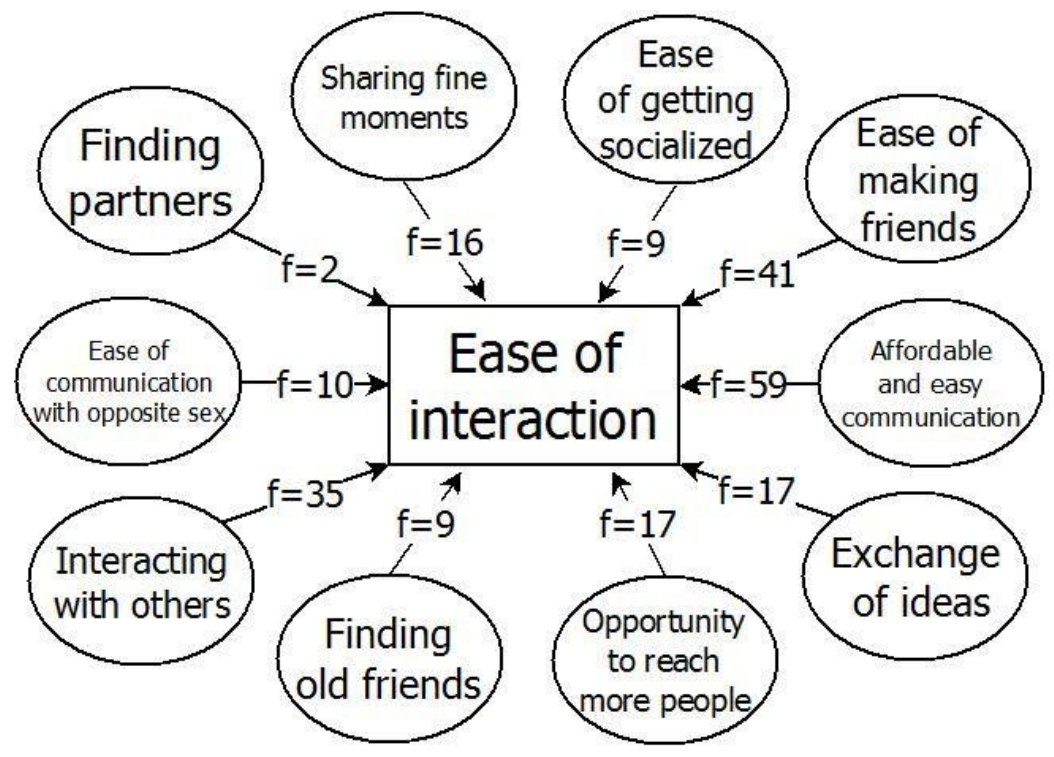

Figure 4. Why does the use of SNS make happy - Ease of interaction

It was seen that the category with the highest frequency was "Affordable and easy communication" ( $f=59$ ) in the ease of interaction theme. This category can be exemplified with Student 50's statement "I think it's also a privilege talking to our loved ones in another corner of the world via social netwo rks every day." The next category is "Ease of making friends" ( $\mathrm{f}=41$ ) which can be exemplified with Student 99's statement "It's easier to make friends. I mean you can meet and chat with someone to whom you're not talking much." The next category in the e ase of interaction theme is "Interacting with others" ( $\mathrm{f}=35$ ) which can be exemplified with Student 71's statem ent "Sharing gives happiness. Social networks make it easier to share with a crowded group in a short term." Student 21's statement "I become happy because I can reach different thoughts of many people on a given subject" can be provided as an example for another category "Exchange of ideas" ( $\mathrm{f}=17$ ). Another category of this theme is "Sharing fine moments" ( $\mathrm{f}=16)$ which can be exemplified with Student 63's statement "I like sharing my photos and enjoy seeing others' photos." Another category of this theme, "Opportunity to reach more people" ( $\mathrm{f}=17)$ can be exemplified with Student 68's statement "I can reach more people and exchange information thanks to usage of social networks." Another category of this theme is "Ease of communication with opposite sex" ( $\mathrm{f}=10)$ which can be exemplified with Student 3's statem ent "If I'm impressed by someone when we're in a café, I can add him/her and chat with right away." "Finding old friends" (f=9) which is another category of this subtheme can be exemplified with Student 49's statem ent "It is a nice thing that you keep in touch with friends you've not seen for a long time and have chance to chat with." Another category of the ease of interaction theme is "Ease of getting socialized" $(\mathrm{f}=9)$ which can be exemplified with Student 81's statement "People who don't have any social circle can satisfy their loneliness by making friends on social networks and meet their need for belonging. They somehow get socialized there." The final category of this theme is "Finding partners" (f=2). Student 
67's statement "It's now easier for people to meet each other with check-in features thanks to certain applications" can be provided as an example for this category.

\section{Ease of accessing and disseminating information}

Another theme associated with why does the use of SNS make happy is "Ease of accessing and disseminating the information" given in Figure 5. The following categories were observed in ease of accessing and disseminating information: "Easy and fast information sharing", "Finding help for homework", "Guiding and informing a group", "Learning new things easily", "Sharing fine moments", "Exchange of ideas", "Interacting with others", a nd "Seeing others' happiness".

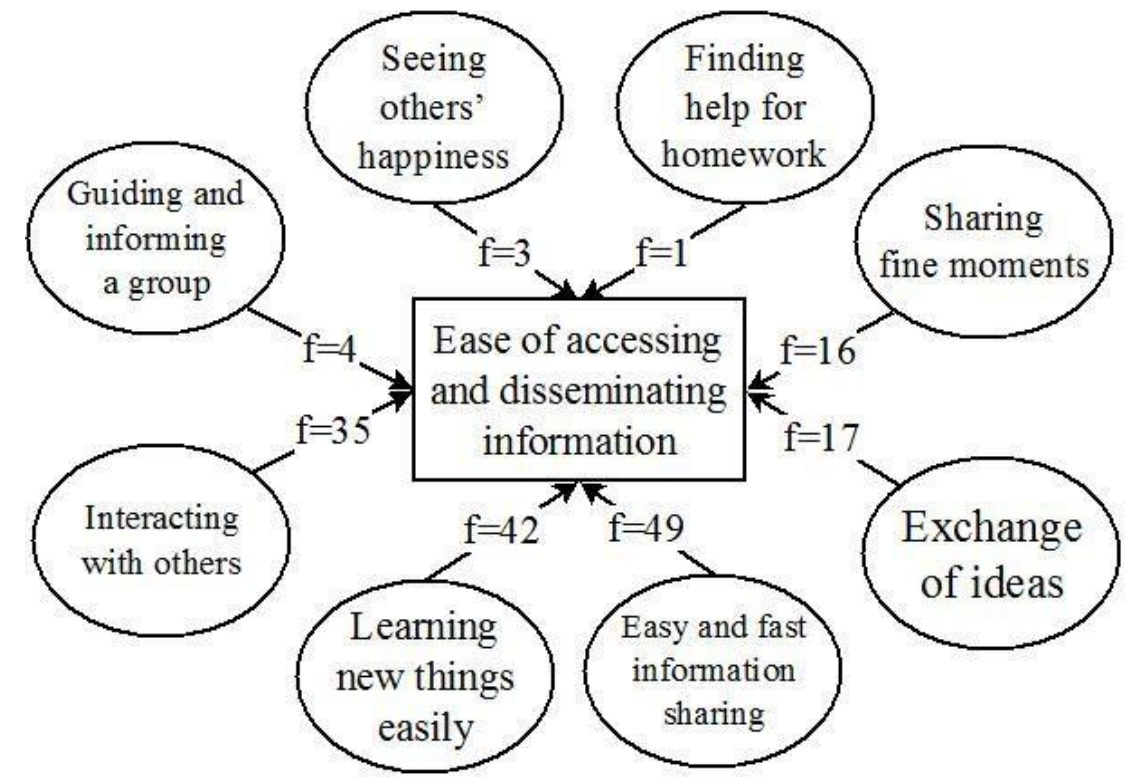

Figure 5. Why does the use of SNS make happy - ease of accessing and disseminating information

The category with the highest frequency was found to be "Easy and fast information sharing" ( $\mathrm{f}=49$ ) in this theme. Student 30's statement "I become happy because I can follow and access latest news and developments via social networks" can be presented as an example for this category. "Learning new things easily" ( $\mathrm{f}=42$ ) which is another category in this theme can be exemplified with Student 127's statement "I read practical information to facilitate my daily life." "Interacting with others" ( $\mathrm{f}=35$ ) which is another category of this subtheme can be exemplified with Student 34's statem ent "It provides me with an environment through which I can reach someo ne when I feel the need." Another category, "Exchange of ideas" (f=17), can be exemplified with Student 122's statement "I want to see the reactions toward my posts or our mutual posts; in other words, it makes me happy to know what ot hers think." "Sharing fine moments" ( $\mathrm{f}=16$ ) which is another category of this subtheme can be exemplified with Student 88's statement "It makes me feel good to share a fine moment with my friends." "Guiding and informing a group" (f=4) which is another ca tegory in the eas e of accessing and disseminating information can be exemplified with Student 127's statement "We can be faster and more active in the correspondence about school with gro ups created on social networks." The next category in this theme is "Seeing o thers' happiness" ( $\mathrm{f}=3$ ) which can be exemplified with Student 27's statement "I become happy for others when I see them sharing their happy and special moments on social networks." For the final category, "Finding help for home work" ( $\mathrm{f}=1$ ), Student 77's statement "I can receive information from my friends on social networks when I have difficulty with my lessons or presentations" can be presented as an example.

\section{Ease of shopping}

Another theme associated with why does the use of SNS make happy is "Ease of Shopping" given in Figure 6. We can observe the categories "Being aware of campaigns" and "Shopping" in this theme.

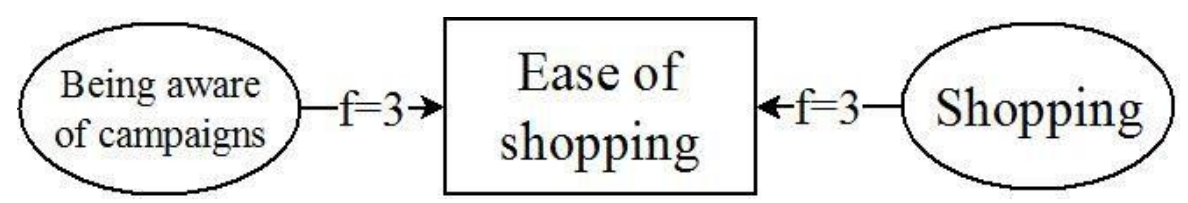

Figure 6. Why does the use of SNS make happy - Ease of shopping

It was seen that the category with the highest frequency was "Being aware of campaigns" ( $\mathrm{f}=3$ ) in ease of shopping. Student 40's statement "I can follow celebrities, brands, concerts and movies actively" can be pres ented as an example for this category. The other and last category of the theme is "Shopping" ( $\mathrm{f}=3$ ) which can be exemplified with Student 29's statement "You can buy products you like." 


\section{Leisure activities}

Another them e associated with why do es the use of SNS make happy is "Leisure activities" given in Figure 7. We can see the categories "Having a good time" and "Making use of free time" in this theme.

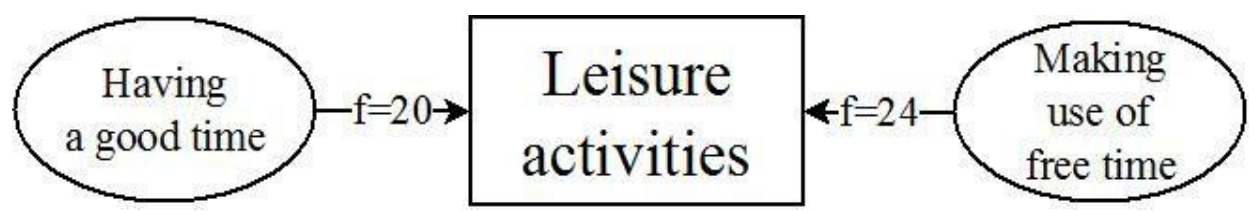

Figure 7. Why does the use of SNS make happy - Leisure activities

It was seen that the category with the highest frequency was "Making use of free time" ( $\mathrm{f}=24)$ in this theme. Student 16 's statement "I see it as a tool through which I spend time during my free time" can be provided as an example for this category. The other and last category of the theme is "Having a good time" ( $\mathrm{f}=20$ ) which can be exemplified with Student 55's statement "I can have a quality time when I browse pages I like and have an interest in in my free time."

\section{Fear of Missing Out}

The final theme associated with why does the use of SNS make happy is "Fear of Missing out" given in Figure 7. We can see that the categori es that constituted the fear of missing out theme are "Being up to date", "Stalking", "Being aware of campaigns", "Checking up on the partner", "Interacting with others", "Satisfying the curiosity", "Learning new things easily", "Being informed of family and friends", "Facilitating ge tting inform ation about others secretly", "Finding gossip material", "Finding old friends", and "Following the celebrities".

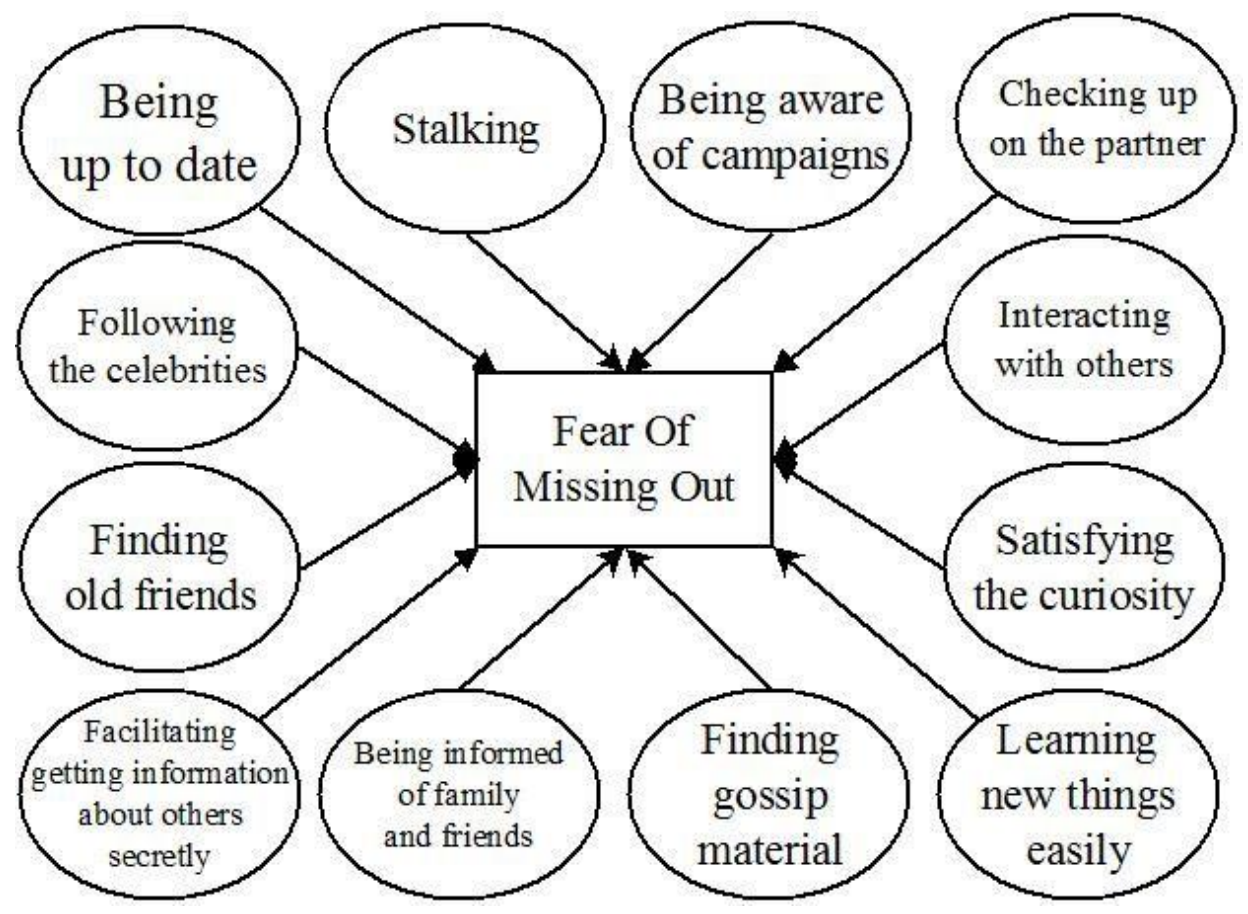

Figure 8. Why does the use of SNS make happy - Fear of missing out

It was observed that there was no category that belonged to the fear of missing out theme. All categories were in other them es. Nevertheless, we can see that thes e categories represent both their own themes and the fear of missing out theme. The following student statements can be provided as examples for the related categories regarding fear of missing out: "We can receive latest news and inform ation on our favorite teams via social networks " (Student 57 in "Being up to date"), "I can access discounts or air dates easily" (Student 112 in "Being aware of campaigns), "You can easily understand whether your boyfriend/girlfriend even do any thing secretly" (Student 23 in "Checking up on the partner"), "I enjoy seeing and knowing where and how people whom I care about or like" (Student 75 in "Interacting with others"), "As they are people that I want to know what they are up to, I satisfy my curiosity by following their pos ts when I want to know what they are up to" (Student 102 in "Satisfying the curiosity"), "I can somehow find people on social networks and become more or less informed of their lives" (Student 59 in "Learning new things easily"), "Knowing and speaking about who does what makes people happy" (Student 5 in "Finding gossip materials"), "I can find out where many friends of mine are, with whom they are and what they do easily at the same moment" (Student 92 in "Being informed of family and friends"), "I can som ehow find people on social networks and become more or less informed of their lives and they don't know about this" (Student 83 in "Facilitating getting information about others 
secretly"), "It helps me see my friends with whom I've not been in touch" (Student 42 in "Finding old friends"), and "It is pleasant to know about them and how they maintain their lives" (Student 117 in "Following the celebrities).

\section{Discussion and Conclusion}

Happiness is associated with the three life spaces which are social interactions, health and work (Lyubomirsky, King, \& Diener, 2005). SNSs facilitate social interactions. If creating social interactions make people happy, SNSs that facilitate such interactions make people happy as well. It has been the conclusions of much research that SNSs make their users happy. Therefore, the reasons lay behind such happiness have gained more attention. Bulut and Do gan (2016) refers that SNS users use SNS with the purposes of work, socialization, joy, communication and mostly of acquisition of information. Rae and Lonborg (2015) concluded that the participants that have lots of friends on Facebook have higher levels of psychological wellbeing. Chou and Edge (2012) stated in their research with 425 undergraduates that students are happier and see life as being fairer when they use Facebook. Do gan (2016) concluded in the study "Effects of social network use on happiness, psychological well-being, and life satisfaction of high school students: case of Facebook and Twitter" that SNS usage of high school students predicted their happiness significantly and positively. Spraggins (2009) found a relations hip between SNS usage and happiness and satisfaction with life. Evasiuk (2016) based his research's focus on relational happiness and jealousy due to the use of Facebook usage. It was found in the questionnaire performed with 124 participants that the participants experience happiness and jealousy due to Fac ebook usage. Kim and Lee (2011) showed that positive number of Facebook friends and positive personal presentation may increase users' subjective well-being level, but this share of happiness is not based on perceived social support. On the other hand, they concluded that honest self-introduction may develop social support-based happiness. Happiness is associated with three key area of life which are social relationships, health, and job (Lyubomirsky, King \& Diener, 2005). SNSs facilitate social relationships. If establishing social relationships makes individuals happy, it can be concluded that SNSs which facilitate establishing these relationships cause happiness, too.

The first theme regarding why SNS usage causes happiness is "Need for appreciation". The categories constituting this them e included "Satisfying the desire of appreciation", "Desire of popularity", "I can say, I'm not alone", "I'm here and I exist, to o", "Making me feel valuable", "Feeling cared about", and "It provides self-confidence." Individuals care about how many likes they get when sharing photos on their social media accounts. Posts on social networks liked by many people recalls primarily the narcissistic attributes. Taylor (2015) emphasized that Facebook satisfies the desires of being loved, appreciated and accepted by others and create an effective communication environment although it is a virtual environment. Witkin (2014) explored in the study with Facebook, Twitter, Instagram and Tumblr users that Facebook users are more narcissistic than Tumblr users but there are narcissistic tendencies on almost equal levels among Twitter and Instagram users. Rosen at all. (2013) argue that use of SNS boost narcissism, because it supports users' narcissism that they pick the photos they share very carefully. Posts on social networks being liked by many people as well as not so many people refer people to not appreciating themselves or the feeling of loneliness. Pittman (2015) emphasized that how students create so much contents or consuming the contents in Twitter and Instagram drags them to loneliness. No matter how SNSs drag individuals to loneliness, individuals do not feel lonely and do become happy as SNSs provide a social circle despite being a virtual environment. Because they receive feedbacks to approve their selves even though it is virtual. This result is also related to "Achieving the idealized self-easier" which is a category of another theme of the research "Self-concealment". Indeed, individuals can hide their real selves with the opportunities offered by SNSs and create a profile to present this profile to others as the self in their dreams. As mentioned above, they become happy as they receive feedbacks that approve their idealized selves. Spraggins (2009) found in the study conducted with 367 university students that there is a relationship between problematic SNS usage and social anxiety. Additionally, loneliness was supported as an intermediary between problematic SNS usage and social anxiety. The study associated problematic SNS usage with loneliness.

Another team is "Self-concealment" which is composed of the subthemes "Stalking" and "Achieving the idealized self easier". These subthemes also have interrelated categories under them. One of the most important problems in adolescent individuals' lives is being appreciated, recognized and embraced by their peers (Taylor, 2015). Adolescents' need for being appreciated by their peers is a more principal factor than reflecting their own personalities (Auty \& Elliott, 2001). For these reasons, some of the SNS users create profiles that do not reflect their own personalities but the way they want others to see or appreciate them on SNS accounts. SNS us ers do not us e their own identities but a virtual identity formed in their imaginations. Agger (2011) us ed the "virtual self" for individuals who are connecting with others via media. Vural and Bat (2010) stated in the study they conducted with university students that $9.7 \%$ of SNS users do not use their own names but different names. In the res earch performed by Dal and Dal (2014) with active SNS users at the age of 15-24, when asked about SNS usage reasons, 143 participants stated that they use them for expressing themselves freely. Kim and Lee (2011) concluded that positive self-pres entation has a direct impact on subjective well-being while honest self-introduction has an importantly indirect impact on subjective well-being of perceived social support when it comes to self-presentation or introduction strategies of SNS users. In other words, it was concluded that SNS users become happier when they introduce themselves as individuals whom they imagine to be. Pempek, Yermolayeva and Calvert (2009) concluded the online concealment in their studies. SNS users can conceal thems elves to get more information about others and minimize the tension and difficulty of face-to-face co mmunication 
when meeting new people, therefore having a more comfortable communication. SNS us ers conceals thems elves online to have inform ation about other users who they interact with without their consent; in other words, they stalk them. It is possible for them to stalk not just the users whom they interact with but also all other SNS users by hacking into their accounts. Yet, certain undesired things can be accessed by excessive stalking. Eterovic-Soric, Choo, Ashman and Mubarak (2017) argue that stalking has become easier with the development of technological tools and widespread usage of smartphones. It is also stated in their study that individuals' addresses can be accessed and several precautions can be taken.

Another theme in the research was found to be "Ease of interaction". The following categories are found in this theme: "Sharing fine moments", "Opportunity to get socialized", "Ease of making friends", "Affordable and easy communication", "Exchange of ideas", "Opportunity to reach more people", "Finding old friends", "Interacting with others", "Ease of communication with opposite sex", and "Finding partners". The use of SNS helps individuals get virtually socialized, therefore causing them to be happy. SNS usage has become popular as it provides users with an easy and affordable environm ent of interaction. Kim, Sohn and Choi (2011) list motivations of SNS users as looking for a friend, social assistance, joy, time spending, and acquisition of information. Yet, the most important motivation of SNS use is stated to be easy access. Moreover, individuals can find friends easily thanks to many SNS usage, and partnerfinding applications are used popularly. Due to these advantages of SNSs, users make new friends and become happier as they are not alone. According to Tandoc at all. (2015), SNS usage even decreases depression as it helps person for socialize and interact in society in the way of intern et. Wang, Jackson, Wang and Gaskin (2015) clai m that SNS increas es the motivation of its us ers and hence, it makes its users happy. What lies behind such motivation and happiness are stated as SNS meets the communication needs and easy access of the users. In a study conducted by Dijk, Dadlani, Halteren and Biemans (2010) with 4 people with spinal cord injury and 8 elders who stay in a nursing home, the participants were provided with camera phones. Via these phones, the participants shared photos and communicated with their families. Therefore, they had an easier communication with their families. SNSs are easy, understandable, simple and affordable enough for even the most disadvantageous groups to interact. Hart (2010) stated in a s tudy with high school and university students that university students use Facebook and they reported that they use it generally for establishing relationships. In their study with the students Chen, Sin, Theng and Lee (2015) find that the students use SNS to increase interactions. Evasiuk (2016) concluded that Facebook usage may affect offline romantic relationships. Substantial number of participants reported that they felt both happy and jealous due to Facebook usage. Things that contribute to these feelings were defined with the way romantic relationships are influenced. Young, LenRios and Young (2017) also state that social media access increases the adolescents' romantic anticipation. In the study performed by Obi (2014) with high school students, it was concluded that more time spent on Facebook means that students' relationships with their friends are affected positively but it has a negative impact on their relationships with their parents. While these students use Facebook every hour of every day of the week, they also reported that they are happy ( $\mathrm{f}=240$ ) or excited ( $\mathrm{f}=239$ ). Vural and Bat $(2010)$ concluded in their study with undergraduates that $6.9 \%$ of the students use Facebook for finding new friends and $18.5 \%$ for online chat.

Another theme achieved in the study is "Ease of accessing and disseminating the information". The categories of this theme are "Easy and fast information sharing", "Finding help for homework", "Guiding and informing a group", "Learning new things easily", "Sharing fine moments", "Exchange of ideas", "Interacting with others", and "Seeing others' happiness". Today, accessing information takes seconds. We do not strive for finding what we are looking for in encyclopedia but access easily and fast everything we are searching on internet via smartphones. In the study conducted by Hether (2009) with two different websites for a month, an example was created to provide 72 support call messages and 1965 support messages. The study was formed with questionnaire data from 114 pregnant women. The ques tionnaire also compared the effects of perceived social support and perceived social capital on outcomes such as prenatal information, attitudes and health behaviors. The results showed that participation of the members who provided more support in the website are more likely to be influenced (Hether, 2009). Goker, Demir and Dogan (2010) asked 486 participants the ques tion "What is the greatest reason why you use internet?" in their res earch. $22.8 \%$ of the participants reported that they use it for getting information and news. SNS users get informed of the age nda by following several news websites via their SNS accounts so that they can get the latest news. This theme does not only include acquiring information on a matter or getting informed of the agenda but also covers getting information on friends or friends and becoming informed of them. In the findings Chen, Sin, Theng and Lee (2015) claim that the students use SNSs for the purpose of getting others' opinions and disseminating their opinions. Vural and Bat (2010) concluded that $9.7 \%$ of the undergraduates in the study use SNS to check what their friends are up to.

Another theme of the study is "Ease of shopping" which has two categories: "Being aware of campaigns" and "Shopping". It is now v ery easy to shop online. Individuals can order anything from anywhere connected to internet via applications on smartphones. They can shop from some popular and cheap shopping sites not only domes tically but also even in China.

Another theme is "Leisure activity" which has two categories: "Having a good time" and "Making use of free time". SNS users check their SNS accounts to make use of their free time. Lin and Lu (2011) state that individuals use social media so as to spend an enjoyable leisure time. In the study conducted by Hart (2010), high school and university students 
reported that they use Fac ebook for spending time. Chen, Sin, Theng and Lee (2015) also refers to spending enjoyable leisure time and spending time in general as reasons to use SNS. Vural and Bat (2010) concluded that 31.0\% of the undergraduates use SNSs for spending time. Dal and Dal (2014) found in their research with SNS users at the ages of 15-24 that 266 of the participants use SNS for spending time.

The final theme of the study is "Fear of missing out". The categories of this theme are "Being up to date", "Stalking", "Being aware of campaigns", "Checking up on the partner", "Interacting with others", "Satisfying the curiosity", "Learning new things easily", "Being informed of family and friends", "Facilitating getting information about others secretly", "Finding old friends", and "Following the celebrities". FoMO does not have its own subthemes because it is nourished by all other themes. FoMO in overall can be sensed as staying update. Chen, Sin, Theng and Lee (2015) also states that generally keeping abreast and staying update are main reasons for students to use SNS.

FoMO has certain negative effects on SNS users. Because SNS users feel the urge to check their social media accounts all the time to be informed of others, which caus es over usage of SNS. Elhai, Levine, Dvorak and Hall (2016) put forth the importance of variables of meeting social needs such as staying in touch as critical mechanisms that can explain FoM0 and problematic smartphone usage and their correlation with depression and a nxi ety. Beyens, Frison and Eggermont (2016) emphasize the importance of the role played by FoMO in adolescent use of media and their well-being. They contributed to our understanding of FoMO's role in the relationships between adol escents' social needs and Facebook usage and the relationship between adolescents' FoMO and the perceived stress about Facebook usage. They concluded that FoMO intermediates the relationships between social needs (i.e. belonging and popularity) and adolescent use of Facebook. They think that FoMO's effect on individuals in their adolescence cannot be ignored. This also shows that FoMO plays a role in the relationship between adolescents' social needs and Facebook usage and this is negatively correlated with the perceived stress level. FoMO sometimes may cause us ers to stay awake permanently. Scoot, Woods and Biello (2017) underline those adolescents using SNSs frequently stay awake and unable to sleep.

SNS users stay in constant communication to s atisfy their feelings of curiosity. To this end, they use several devices and internet packages. They are constantly informed of developments and keep up with the agenda.

The higher level of FoMO SNS users have, the less their general satisfaction with life and general moods will be. Their dependency on SNS will increase and need for psychological satisfaction will decreas e. Campisi, Folan, Diehl, Kable and Rademeyer (2015) indicate that FoMO affects the life quality of people and besides SNS increases its users' quality of life and makes them happy. Przybylski, Murayama, DeHaan and Gladwell (2013) concluded that SNS us ers become happier because they meet their need for psychological satisfaction through FoMO. The reason for this can be explained by the fact that SNS users who experience stress and anxiety as their need for FoMO increases and their stress and anxiety levels decrease after they have connected to a social network and satisfied their curiosity.

\section{Recommendations}

This study was designed as a qualitative study. It would be appropriate to support findings with quantitative analyses such as intermediate variable analysis and structural equation modeling. Furthermore, it is thought that it would be useful to compare research findings for groups such as gender.

According to the findings, youngs ters meet their needs for social interaction through SNSs. Trainings in social skills for these age groups and planning or arranging social activities to increase their interactions would be useful.

As a fact of our era, internet usage and especially SN S us age brings the concept of "risky usage" to mind. The content of Media Literacy course at schools should be designed to prevent possible negativities due to this risky usage. Indeed, besides courses at schools, informative broadcasts should be aired for safe internet and SNS us age via mass media that broadcast on a national scale. Responsibility regarding the risk usage should not be assigned not only to government and teachers but parents should also assume important roles in these intervention programs.

\section{References}

Acir, E. (2009). Internet'in Turk toplumunun iletisimindeki rolu: Facebook'taki Turkiye [The role of internet in the communication of Turkish society: The Turkey in Facebook] (Unpublished Master's Thesis). Ankara University, Ankara/Turkey.

Agger, B. (2011). Sanal benlik [The Virtual self]. (V. Hacioglu, Trans.) Istanbul: Babil Yayinlari.

Auty, S., \& Elliott, R. (2001). Being like or being liked: Identity vs. approval in a social context. ACR North American Advances, 28, 235-241. Retrieved from http://acrwebsite.org/volum es/8475/volumes /v28/NA-28, on 23.08.2017.

Balci, A. (2015). Sosyal bilimlerde arastirma yontem, teknik ve ilkeler [Research methods, techniques and principles in social sciences], (11th Edition). Ankara: Pegem Akademi. 
Beyens, I., Frison, E., \& Eggermont, S. (2016). "I don't want to miss a thing”: A adolescents' fear of missing out and its relationship to adolescents' social needs, Facebook use, and Facebook related stress. Computers in Human Behavior, 64, 1-8. DOI: https://doi.org/10.1016/j.chb.2016.05.083

Blackwell, D., Leaman, C., Tramposch, R., Osborne, C., \& Liss, M. (2017). Extrav ersion, neuroticism, attachment style and fear of missing out as predictors of social media use and addiction. Personality and Individual Differences, 116, 69-72. DOI: https://doi.org/10.1016/j.paid.2017.04.039

Boyd, D. M., \& Ellison, N. B. (2008). Social network sites: Definition, history, and scholarship. Journal of ComputerMediated Communication, 13, 210-230.

Buckle, C. (2017). The mobile tipping point is happening among 16-24s. Retrieved from http://blog.globalwebind ex.net/chart-of-the-day/the-mobile-tipping-point-is-happening-among-16-24s/, 23.08.2017.

Bulut, Z. A., \& Dogan, O. (2017). The ABCD typology: Profile and motivations of Turkish social network cites users. Computers in Human Behavior, 67, 73-83. DOI: https://doi.org/10.1016/j.chb.2016.10.021

Bulbul, S., \& Giray, S. (2011). Sosyodemografik ozellikler ile mutluluk algisi arasindaki iliski yapisinin analizi [Analysis of the relationship structure between socio-demographic features and happiness sensation]. Ege Academic Review, $11,113-123$.

Buyukozturk, S., Kilic Cakmak, E., Akgun, O. E., Karadeniz, S., \& Demirel, F. (2014). Bilimsel arastirma yontemleri [Scientific research methods] (18th Edition). Ankara: Pegem Akademi.

Campisi, J., Folan, D., Diehl, G., Kable, T., \& Rademeyer, C. (2015). Social media users have different experiences, motivations, and quality of life. Psychiatry Research, 228(3), 774-780. D0I: https://doi.org/10.1016/j.psychres.2015.04.042

Chen, X., Sin, S.-C. j., Theng, Y.-L., \& Lee, C. S. (2015). Why student share misinform ation on social media: Motivation, gender and study level differences. The Journal of Academic Libraainship, 41, 583-592. D0I: https://doi.org/10.1016/j.ac alib.2015.07.003

Chou, H. -T. G., \& Edge, N. (2012). "They are happier and having better lives than I am”: the impact of using Facebook on perceptions of others' lives. Cyberpsychology, Behavior and Social Networking, 15(2), 117-121. D0I: https://doi.org/10.1089/cyber.2011.0324

Dal, N. E., \& Dal, V. (2014). Kisilik ozellikleri ve sosyal ag sitesi kullanim aliskanliklari: Universite ogrencileri uzerine bir arastirma [Personality traits and social network sites usage habits: A Research on university students]. Mehmet Akif Ersoy University Journal of Social Sciences Institute, 6(11), 144-162.

van Dijk, B., Dadlani, P., van Halteren, A., \& Biemans, M. (2010, August). Life changes, connection stays: photo sharing and social connectedness for people with special needs. In Proceedings of the 28th Annual European Conference on Cognitive Ergonomics (pp. 135-142). ACM..

Dogan, U. (2016). Effects of social network use on happiness, psychological well-being, and life satisfaction of high school students: Case of Facebook and Twitter. Education and Science, 41(183), 217-231. D0I: https://doi.org/10.15390/EB.2016.4616

Elhai, J. D., Levine, J. C., Dvorak, R. D., \& Hall, B. J. (2016). Fear of missing out, need for touch, anxi ety and depression are related to problematic smartphone use. Computers in Human Behavior, 63, 509-516. D0I: https://doi.org/10.1016/j.chb.2016.05.079

Ellison, N. B., Steinfield, C. \& Lampe, C. (2007). The benefits of Facebook "friends": Social capital and college students' use of online social network sites. Journal of Computer-Mediated Communication, 12(4), 1143-1168. DOI: https://doi.org/10.1111/j.1083-6101.2007.00367.x

Eren, F., Celik, I., \& Akturk, A. O. (2014). Ortaokul ogrencilerinin Facebook algisi: Bir metafor calismasi [Secondary school students' perceptions of Facebook: A Metaphor analysis]. Kastamonu Education Journal, 22(2), 635-648.

Eryilmaz, A. (2011). Ergen oznel iyi olusunun, oznel iyi olusu arttirma stratejilerini kullanma ile yasam amaclarini belirleme acisindan incelenmesi [Investigating adolescents' subjective well-being with respect to using subjective well-being increasing strategies and determining life goals]. Dusunen Adam: Journal of Psychiatry \& Neurological Sciences, 24, 44-51. doi: https://doi.org/10.5350/DAJPN2011240106

Eterovic-Soric, B., Choo, K.-K. R., Ashman, H., \& Mubarak, S. (2017). Stalking the stalkers - detecting and deterring stalking behaviours using technology: A Review. Computers \& Security, 70, 278-289. Retrieved from https://doi.org/10.1016/j.cose.2017.06.008, on 21.08.2017. 
Evasiuk, A. (2016). The impact of Facebook use on romantic relationships, (Unpublished Mas ter's Thesis). University of Alberta, Alberta/USA.

Goker, G., Demir, M., \& Dogan, A. (2010). Ag toplumunda sosyallesme ve paylasim: Facebook uzerine ampirik bir arastirma (Socialization and sharing in the network society: an empirical research on Fac ebook). e-Journal of New World Sciences Academy, 5(2), 183-206.

Hart, M. J. (2010). A study on the motives of high school and undergraduate college students for using the social network site Facebook, (Unpublished Doctoral Thesis). Liberty University, Virginia/USA.

Hether, H. J. (2009). Social media and health: social support and social capital on pregnancy-related social networking sites, (Unpublished Doctoral Thesis). University of Southern California, California/USA.

Kahneman, D., Diener, E., \& Schwarz, N. (1999). Wellbeing: The Foundations of hedonic psychology. New York: Russel Sage.

Kane, G. C., Fichman, R. G., Gallaugher, J., \& Glaser, J. (2009). Community relations 2.0. Harvard Business Review, 87, 4550.

Kemp, S. (2017). Digital in 2017 global overview. Retrieved from https://wearesocial.com/special-reports/digital-in2017-global-overview, on 15.07.2017.

Kim, J. \& Lee, J.-E. R. (2011). The Facebook paths to happiness: Effects of the number of Facebook friends and selfpresentation on subjective well-being. Cyberpsychology, Behavior, and Social Networking, 14(6). D0I: https://doi.org/10.1089/cyber.2010.0374

Kim, Y., Sohn, D., \& Choi, S. M. (2011). Cultural difference in motivations for using social network sites: A Comparative study of American and Korean college students. Computers in Human Behavior, 27, 365-372. D0I: https://doi.org/10.1016/j.chb.2010.08.015

Koc, M., \& Karabatak, M. (2012). Sosyal aglarin ogrenciler uzerindeki etkisinin veri madenciligi kullanilarak inc el enm esi [Investigation of the effect of social networks on students by using data mining]. e-Journal of New World Sciences Academy, 7(1), 155-164.

Kwon, O. \& Wen, Y. (2010). An empirical study of the factors affecting social network service use. Computers in Human Behavior, 26, 254-263. DOI: https://doi.org/10.1016/j.chb.2009.04.011

Layard, R. (2005). Happiness: Lessons from a new science. London: Penguin Books.

Lin, K.-Y., \& Lu, H.-P. (2011). Why people use social networking sites: An Empirical study integrating network externalities and motivation theory. Computer in Human Behavior, 27(3), 1152-1161. DOI: https://doi.org/10.1016/j.chb.2010.12.009

Lyubomirsky, S., King, L. \& Diener, E. (2005). The benefits of frequent positive affect: Does happi ness lead to success? Psychological Bulletin, 131(6), 803-855. DOI: https://doi.org/10.1037/0033-2909.131.6.803.

Malik, A., Dhir, A. \& Nieminen, M. (2016). Uses and gratifications of digital photo sharing on Facebook. Telematics and Informatics, 33(1), 129-138. DOI: https://doi.org/10.1016/j.tele.2015.06.009

Mander, J. (2015). Internet users have average of 5.54 social media accounts. Retrieved from http://blog.globalwebind ex.net/chart-of-the-day /internet-users-hav e-average-of-5-54-social-media-accounts/, on 25.08.2017.

McAndrew, F. T., \& Jeong, H. S. (2012). Who does what on Facebook? Age, sex, and relationship status as predictors of Facebook use. Computers in Human Behavior, 28(6), 2359-2365. DOI: https://doi.org/10.1016/j.chb.2012.07.007

McGrath, F. (2017). Top 10 reasons for using social media. Retri eved from http://blog.globalwebi nd ex.net/chart-of-theday/social-media/, on 25.08.2017.

Murray, C. (2008). Schools and social networking: Fear or education. Synergy, 6(1), 8-12.

Muscanell, N. L. \& Guadagno, R. E. (2012). Make new friends or keep the old: Gender and personality differences in social networking use. Computers in Human Behavior, 28(1), 107-112. D0I: https://doi.org/10.1016/j.chb.2011.08.016

Oberst, U., E. W., Stodt, B., Brand, M., \& Chamarro, A. (2017). Negative consequences from heavy social networking in adolescents: The Mediating role of fear of missing out. Journal of Adolescence, 55, 51-60. DOI: https://doi.org/10.1016/j.adolescence.2016.12.008,

Obi, A. N. (2014). Time spent on Facebook vs. total time spent online: Effects on the quality of life of high school students, (Unpublished Doctoral Thesis). Golden Gate University, California/USA. 
Patton, M. Q. (2014). Nitel arastirma ve degerlendirme yontemleri [Qualitative research and evaluation methods]. (M. Butun; S. B. Demir, Trans. Ed.). Ankara: Pegem Akademi.

Pempek, T. A., Yermolayeva, Y. A., \& Calvert, S. L. (2009). Coll ege students' social networking experiences on Facebo ok. Journal of Applied Development Psychology, 30(3), 227-238. DOI: https://doi.org/10.1016/j.appdev.2008.12.010, on 25.08.2017.

Pfeil, U., Arjan, R., \& Zapharis, P. (2009). Age differences in online social networking: A Study of user profiles and the social capital divide among teenagers and older us ers in Myspace. Computers in Human Behavior, 25, 643-654. D0I: https://doi.org/10.1016/j.chb.2008.08.015

Pittman, M. (2015). Creating, consuming and connecting: Examining the relationship between social media engagement and loneliness. The Journal of Social Media in Society, 4(1), 66-98. Retrieved from http://www.thejsms.org/tsmri/index.php/T SMRI/article/view/92/52, on 25.08.2017.

Pittman, M. \& Reich, B. (2016). Social media and loneliness: Why an Instagram picture may be worth more than a thousand Twitter words. Computers in Human Behavior, 62, $155-167$. https://doi.org/10.1016/j.chb.2016.03.084

Powell, J. (2009). 33 Million people in the room: How to create, influence, and run a successful business with social networking. New Jersey: FT Press.

Przybylski, A. K., Murayama, K., DeHaan, C. R., \& Gladwell, V. (2013). Motivational, emotional, and behavioral correl ates of fear of missing out. Computers in Human Behavior, 29, $1841-1848$. https://doi.org/10.1016/j.chb.2013.02.014

Rae, J. R. \& Lonborg, S. D. (2015). Do motivations for using Facebook moderate the association between Facebook use and psychological well-being? Frontiers in Psychology, 6. DOI: https://doi.org/10.3389/fpsyg. 2015.00771

Robson, C. (2015). Bilimsel arastirma yontemleri gercek dunya arastirmasi [Real World Research] (1st Edition). (S. Cinkir; N. Demirkasimoglu, Trans. Ed.) Ankara: Ani Yayincilik.

Rosen, L. D., Whaling, K., Rab, S., Carrier, L. M., \& Cheever, N. A. (2013). Is Facebook creating "iDisorders"? The link between clinical symptoms of psychiatric disorders and technology use, attitudes and anxiety. Computers in Human Behavior, 29(3), 1243-1254. DOI: http://dx.doi.org/10.1016/j.chb.2012.11.012

Ross, C., Orr, E. S., Sisic, M., Arseneault, J. M., Simmering, M. G., \& Orr, R. R. (2009). Personality and motivations associated with Facebook use. Computers in Human Behavior, 25, 578-586. D0I: https://doi.org/10.1016/j.chb.2008.12.024

Scott, H., Woods, H. C., \& Biello, S. M. (2017). Bedtime social media use in adolescence: Underlying motivations and impact on sleep. Sleep Medicine, 40(1), e298. DOI: https://doi.org/10.1016/j.sleep.2017.11.876

Sidekli, S. (2013a). Media literacy: Experiences of 6th 7th and 8th graders. International Journal of Academic Research, 5(1), https://doi.org/143-159. 0.7813/2075-4124.2013/5-1/B.24

Sidekli, S. (2013b). Media literacy: Perspectives from elementary school children's views. International Journal of Academic Research, 5(2), 201-210.

Spraggins, A. (2009). Problematic use of online social networking sites for college students: Prevalence, predictors, and association with well-being, (Unpublished Doctoral Thesis). University of Florida, California/USA.

Sener, G. (2009). Turkiye'de Facebook kullanimi arastirmasi. [A study of use facebook in Turkey] Paper presented at the INET 14. Conference Internet in Turkey, Istanbul.

Tandoc Jr., E. C., Ferrucci, P., \& Duffy, M. (2015). Facebook use, envy, and depression among college students: is Facebooking depressing? Computers in Human Behavior, 43, 139-146. Retrieved from https://doi.org/10.1016/j.chb.2014.10.053, on 17.08.2017.

Tapscott, D. (2008). Grown up digital: how the next generation is changing your world. New York: McGraw-Hill.

Taylor, I. H. (2015). Facebook and the being liked motive. International Journal of Social Sciences and Education Research, 1(4), 1473-1486. Retrieved from http://dergipark.ulakbim.gov.tr/ijsser/, on 23.08.2017.

Tifferet, S. \& Vilnai-Yavetz, I. (2014). Gender differences in Facebook self-presentation: an international randomized study. Computers in Human Behavior, 35, 388-399. DOI: https://doi.org/10.1016/j.chb.2014.03.016

Turkish Statistical Institute. (2016). Hanehalki bilisim teknolojileri kullanim arastirmasi [Information and communication technology (ict) usage survey on households and individuals]. Retrieved from www.tuik.gov.tr, on 12.08.2017. 
Turkish Statistical Institute. (2017). Adrese dayali nufus kayit sistemi sonuclari, 2016 [The results of address based population registration system, 2016]. Retrieved from www.tuik.gov.tr, on 12.08.2017.

Turkish Language Association (TDK) (2011). Guncel Turkce Sozluk [Contemporary Turkish Dictionary]. Retriev ed from www.tdk.gov.tr, on 12.08.2017.

Valkenburg, P. M., Peter, J. \& Schouten, A. P. (2006). Friend networking sites and their relationship to adol escents' well being and social self-esteem. CyberPsychology \& Behavior, 9(5), 584-590. D0I: https://doi.org/10.1089/cpb.2006.9.584

Vural, Z. B. \& Bat, M. (2010). Yeni bir iletisim ortami ol arak sosyal medya: Ege Universitesi Il etisim Fakultesine yonelik bir arastirma (Social media as a new communication environment: A Research on Ege University Faculty of Communication). Journal of Yasar University, 20(5), 3348-3382.

Wang, J.-L., Jackson, L. A., Wang, H. -Z., \& Gaskin, J. (2015). Predicting social networking site (SNS) use: Personality, attitudes, motivation and internet self-efficacy. Personality and Indivual Differences, 80, 119-124. D0I: https://doi.org/10.1016/j.paid.2015.02.016

Witkin, N. D. (2014). The role of persona lity, attachment, and narcissism in regards to social networking: AN Examination of socialnetwork users, (Unpublished Doctoral Thesis). Alliant International University, San Diego/USA.

Yildirim, A. \& Simsek, H. (2013). Sosyal bilimlerde nitel arastirma yontemleri [Qualitative research methods in social sciences] (9th Edition). Ankara: Seckin Yayincilik.

Young, K. (2016). Mobiles capture 50\% of time for 16-24s. Retriev ed from http://blog.globalwebi ndex.net/chart-of-theday/mobiles-capture-50-of-time-for-16-24s/, on 21.08.2017.

Young, R., Len-Rios, M., \& Young, H. (2017). Rom antic motivations for social media use, social comparison, and online aggression among adolescents. Computers in Human Behavior, 75, 385-395. D0I: https://doi.org/10.1016/j.chb.2017.04.021 